\title{
The Changing Nature of Work in Academic Libraries
}

\section{Beverly P. Lynch and Kimberley Robles Smith}

\begin{abstract}
A content analysis of 220 job advertisements that appeared in College \& Research Libraries between 1973 and 1998 demonstrates that by 1998, all academic library jobs routinely included computer technologies, that instruction had become an integral part of reference work, and that behavioral skills, especially oral and written communication skills, had emerged as new job requirements. The master's degree from a program accredited by the ALA continues to be widely accepted as the appropriate professional degree for academic librarians.
\end{abstract}

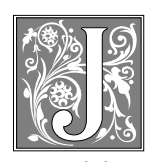

ob change is the topic of this investigation. The changing nature of library work is a subject of continuing interest to practitioners, educators, and researchers. Of growing importance is the particular question of how computer technology is changing jobs and being assimilated into all aspects of academic librarianship and how the new technologies may be influencing change, not only in library work, but also in the profession itself.

Changes in the actual jobs of librarians and the requirements for those jobs influence change in organizational structures. Beverly P. Lynch's earlier investigations evaluated the nature of the work according to functional library departments. ${ }^{1}$ These departments were in the divisions of technical and public services, the long-standing organizational design of academic libraries. Administrative units were outside the framework of her investigation; rather, her focus was on the central characteristics of the work carried out in libraries. She described the department's work by collapsing individual job characteristics into a score for each department. The present investigation is of individual jobs, with a particular emphasis on identifying specific job characteristics that are new. The analysis reported in this article forms the base for further work on the unit and organizational structures.

A content analysis was conducted of advertisements for jobs in American academic libraries that appeared in College $\mathcal{E}$ Research Libraries News (CERL News) over a twenty-five-year period. Not all academic libraries advertise nationally nor are they willing to wait the six to nine months (or more) from submission of an ad to a national publication to appointment of a new librarian. For purposes of this analysis, it was assumed that librar-

Beverly P. Lynch is a Professor in the Graduate School of Education and Information Studies at UCLA and Interim President of the Center for Research Libraries; e-mail: bplynch@ucla.edu. Kimberley Robles Smith is the Reference and Multicultural Librarian at California State University, Fresno; e-mail: kimberle@csufresno.edu. An earlier version of this paper was presented at the 1999 ACRL Conference in Detroit. 
ies advertising nationally would likely identify job changes and structural changes of enough importance to describe them in national advertisements. Thus, the assumption was that libraries seeking a national pool of job applicants would develop job descriptions that reflected the current trends and job requirements of the profession as a whole. Many academic libraries advertise locally or regionally, and these libraries also could provide important sources of data. For the purposes of this investigation, however, the authors selected a national data source that was readily available and replicable.

\section{Previous Investigations}

Most of the studies based on job advertisements in library and information science (LIS) have had as their purpose an analysis of the job market and the predictions of employment trends. In 1980, David Block analyzed job announcements in a file maintained by the Graduate School of Library and Information Science at the University of Texas at Austin. ${ }^{2}$ Cataloging and reference positions comprised nearly half the total jobs listed there.

\section{The overall objective is to assess how the nature of academic library work has changed-and continues to change-and how the change is reflected in organizational structures and design.}

David W. Reser and Anita P. Schuneman did a content analysis of 1,133 technical and public services positions advertised in American Libraries, CERL News, and Library Journal in 1988. They found that technical services jobs required more computer skills, greater foreign-language requirements, and previous work experiences. ${ }^{3}$ Public services jobs required more advanced degrees. Penny M. Beile and Megan M. Adams updated the ReserSchuneman investigation using nine hundred job announcements that appeared in the 1996 issues of American Libraries, Chronicle of Higher Education, CERL News, and Library Journal. ${ }^{4}$ Beile and Adams compared jobs in public services, technical services, and, a new category, electronic services. Computer skills required in public and technical services jobs were similar. Electronic services jobs were more detailed in their computing requirements. Although the ALA-accredited degree remained very important in the technical and public services jobs (required by $93 \%$ of the jobs advertised), it was requested in only 76.3 percent of the electronic services jobs. Thus, the ALA-accredited degree appeared to be less important for new hires.

Hong $\mathrm{Xu}$ did a content analysis of job ads appearing in American Libraries between 1971 and 1990 to identify similarities and differences in the jobs of catalog librarians and reference libraries working in academic libraries. He was particularly interested in identifying jobs brought about by developments in library automation. After analyzing 574 jobs stratified into four periods representing technological change in libraries (1971-1975, 19761980,1981-1985, and 1986-1990), he found increasing needs for computer skills in both groups. ${ }^{5}$ However, differences remained in the major job responsibilities and in the knowledge and skills needed.

William C. Robinson, seeking to identify skills and experiences required for collection development jobs, analyzed 433 ads that appeared in CERL News between 1980 and $1991 .{ }^{6}$ Fifty-eight percent of the ads (251) combined collection development jobs with another function; about 80 percent of these were combined with reference jobs. Seventy-nine percent of the positions required degrees from ALA-accredited programs; only 231 of the ads mentioned faculty status. Robinson also included a good review of the literature on the use of job ads to assess the nature of library work.

Zhou Yuan analyzed trends in requirements for computer skills in academic library jobs. ${ }^{7}$ He found that jobs in technical and public services in 1994, the last year of his analysis, required specific computer skills. Further, nearly 88 percent of administrative positions listed computer- 
related qualifications. Zhou concluded that knowledge of computing now is integral to all jobs in academic libraries.

Margaret Foote analyzed systems librarian positions in academic libraries by reviewing position announcements in CERL News between 1990 and 1994. ${ }^{8}$ She found that experience with technology was the skill most often required. She also observed that there was a wide variety of position titles and that about 66 percent of them required the MLS degree.

Other analyses of job ads included an assessment of head of reference positions in academic libraries between 1990 and 1999, archivist positions between 1976 and 1990, serials cataloger positions between 1980 and 1995, academic specialist positions between 1990 and 1998, preservation librarians between 1975 and 1987, and serials positions between 1980 and $1988 .^{9-14}$

Using a different methodology, Lois Buttlar and Rajinder Garcha surveyed 271 catalogers to determine the change they identified in their work activities and roles between 1987 and $1997 .{ }^{15}$ More than 90 percent of the respondents reported that the core activities of their jobs remained the same-descriptive cataloging and the assignment of call numbers and subject headings, activities long associated with their careers. However, the catalogers did report that their roles had expanded to include managerial tasks, the training of others, and the inclusion of electronic materials. Buttlar and Garcha also found that some catalogers were becoming involved in activities relating to database development and maintenance. A small, but growing, number of catalogers reported being engaged in reference desk work, collection development, and bibliographic instruction, with job-sharing on the rise.

Joan Giesecke, Sarah Michalak and Brinley Franklin wrote a paper that discussed the jobs of associate directors in academic libraries. They sought to determine what the roles of senior managers were in 1997. To do this, they compared assistant university librarian job an- nouncements in 1985 and in 1994-1995. Although they did not identify the source of the job announcements or the numbers of announcements reviewed, they did identify some new terminology. Their conclusion was that "most senior management positions remained structurally the same." 16

The Association of Research Libraries (ARL) surveyed its members in January 1999 to examine descriptions of positions posted in 1996, 1997, and 1998. The fifty-five libraries responding to the survey had posted 686 librarian positions and 206 administrative positions during the period. New skills emerging from this survey emphasized technology. Reference positions included knowledge of electronic resources, and some jobs required knowledge of markup languages (HTML, SGML, XML) and operating systems (Unix, Windows, and Macintosh). In addition, many positions asked for team skills. Typical language included statements on teamwork, communication, and shared responsibility. ${ }^{17}$

Lynch's early studies of the work of functional units in major research universities used survey methods to study the jobs of professional and nonprofessional staff. ${ }^{18}$ She aggregated individual scores in order to develop a score with which to compare the complexity of work carried out in library departments. Conducted in the 1970s and 1980s, her data included jobs that were relatively stable and well understood. Jobs using computing technologies were exceptional and specialized. Computing had not been made a routine part of the academic libraries' work at the time of her investigations. Based on the aggregated scores, reference departments emerged with the most nonroutine work.

\section{Questions Guiding This Study}

The present study investigates library jobs in an effort to understand the nature and content of current and emerging jobs in academic libraries. The overall objective is to assess how the nature of academic library work has changed-and 
continues to change-and how the change is reflected in organizational structures and design. One might expect that change in work would lead to change in organizational structure and design. This study, the first step toward that understanding, seeks to systematically identify specific changes in library jobs. The questions that guided this investigation include:

- Did the jobs advertised in the 1990s show significant changes in content over those advertised in the 1970s and 1980s?

- How widespread are job requirements relating to technology? That is, do more jobs include specific technologies in their requirements?

- Do behavioral skills such as "ability to work in a team environment" appear more frequently? Were behavioral requirements found in ads in the 1970s and 1980s?

- From job ads, can any changes be observed in the administrative patterns in academic libraries and their functional units?

\section{Methodology}

A content analysis of job advertisements was selected as the methodology for this study. The assumption is that the ad will indicate the ideal job as defined by the employer and that the library will include in it the knowledge, skills, and abilities the library believes to be important at that particular point in time. The ad defines the job without making the necessary adjustments to it when a person is already in place. Because the authors were looking for indicators of changes in library work, the ideal design is what they sought.

A total of 220 job advertisements in CERL News for the month of March in the years 1973, 1983, 1988, 1993, and 1998 were used in the analysis. The authors selected CERL News because jobs advertised in it reach a national audience, not a regional or local audience. (ACRL had about 12,000 members in 2000.) It was assumed that these jobs would reflect change occurring in academic libraries and thus display a variation over time.
The year 1973 was used as a baseline. Although technology had been a topic of interest beginning in the 1960s, it was a new and unusual activity in the early 1970s. In their text on university library administration published in 1971, Rutherford D. Rogers and David C. Weber anticipated the use of computers and the impact of automation on university libraries. ${ }^{19}$ They offered good advice on how to proceed and what to anticipate. They recommended that library automation efforts be placed initially in a single division or department, with separate functions from, but equal status with, the traditional library departments. Rogers and Weber also expected the production responsibilities initially placed in the automation or systems department to be transferred at some point to the traditional departments, with the automation unit continuing with maintenance and development. This model was workable and is the one found today in most large academic libraries. As identified by Reser and Schuneman and others, computing skills are pervasive in library jobs and are needed in technical and public services jobs. Beile and Adams found that electronic services jobs had more specific and detailed technical requirements than the regular technical and public services jobs. Their findings reinforced Rogers and Weber's prediction that an automation unit would continue with maintenance and development responsibilities.

The seminal paper by Arthur M. McAnally and Robert B. Downs on the changing role of directors of university libraries was published in March 1973.20 In it, McAnally and Downs described the university library's environment as one of turbulence and change, and commented on the difficulty of dealing with the information explosion. They mentioned technology as a promising means of coping with the knowledge explosion and the flood of materials but showed their disappointment in the meager progress in adapting technology to research libraries. Their disappointment was expressed in the following quote from one of their respondents: 
Computerization of information, long hoped by some to be the solution to library costs, is for that purpose substantially bankrupt. ${ }^{21}$

There was much publication about, and some experimentation in using, library technology to control the flood of materials and to control costs. However, in 1973, most academic libraries still were operating in the traditional model. The emphasis on collection development and technical services remained primary.

This is the reason the authors selected 1973 as a baseline; the selection of March was arbitrary.

The job categories used in this analysis were based on those used in the 1999 conference placement center of the ALA. The eleven categories used in this study are as follows:

A. Administration (deans, directors, AULS, etc.)

Al. Other administrative positions (personnel officer, etc.)

A2. Head of a subject library (chemistry, art, etc.)

A3. Head of a library dept. (function: reference, cataloging, etc.)

D. General and subject reference.

El. Instruction librarian. (coordinator of instruction)

E2. Extension/distance learning librarian.

F. Technical services (acquisitions, cataloger, serials).

H. Collection development.

I . Special materials (any position), government documents, maps, rare books, archives, audiovisual, etc.

J. Information systems (automation, bibliographic utilities, networks, systems, etc.)

Table 1 lists the number of positions advertised by job title and date. The title was used to classify the job. If the title was not descriptive enough, assignment of an ad in a particular job category was determined by the ad's content.

Eighty-four (38\% of all ads) were for administrative jobs. Of these, forty-five $(20 \%)$ were for jobs classed in A (deans, directors, AULS, etc.). Twenty-nine (14\%) were department head positions. Reference jobs totaled $30(14 \%)$, with technical services jobs and jobs combining reference and collection development totaling 10 percent each.

The Classification of Institutions of Higher Education, published in 1994 by the Carnegie Foundation for the Advancement of Teaching, was used to classify the libraries that were advertising. The foundation is testing a change in its classification scheme. ${ }^{22}$ The 1994 categories were used because they are well known and well understood. Over the period studied, institutions could move into different classifications; the categories themselves remained much the same. The classifications used were: Research Universities, Doctoral Universities, Master's (Comprehensive) Colleges and Universities, Baccalaureate (Liberal Arts) Colleges, and Associate of Arts Colleges. Although the 1994 Carnegie Classification includes two groupings in most classes, groups I and II in each category were collapsed into a single class in this study.

Table 2 shows the distribution of the ads. Forty-eight percent of them were for jobs in libraries serving research universities. Of the 3,595 institutions included in the 1994 Carnegie Classification, 125 $(3 \%)$ were research universities. Although it is likely that jobs in various functional units were advertised locally, the authors assumed that these large libraries were better able to design new jobs reflecting new demands in work than smaller libraries were. The authors also assumed that the large libraries have more freedom to experiment with new job designs than small libraries do and expected that a national pool would be sought for newly designed jobs. Historically, the large libraries have pioneered much of the technical change in academic libraries. Both the research libraries, particularly those with separate libraries for undergraduates, and the liberal arts colleges developed innovative instructional programs beginning in the 1960s and early 1970s. 
The authors did a small pilot study of twelve jobs advertised in the February 1998 issue of Chronicle of Higher Education to assess coding and to determine the presence of some of the variables. Of the jobs advertised, seven had traditional titles (e.g., social science reference librarian, assistant/associate director of technical services). One ad displayed a title that extended the reference librarian's job-information services librarian. Two jobs had what the authors called emerging titles (e.g., access services manager). One job, advertised by a Research I university, was given an innovative or new title-information consultant. Surprisingly, there were no ads in the El category of instruction librarian.

To assess job content relating to computing, the authors used the checklist of computer-related codes developed and used by Zhou. ${ }^{23}$ The computer codes used were:

1. bibliographic utilities, such as OCLC or RLIN;

2. automated library systems, including general knowledge library automation;

3. online database searching, such as DIALOG or BRS;

4. microcomputer applications;

5. mainframe computer applications;

TABLE 1

Positions Advertised by Job Title

\begin{tabular}{lcccccc} 
Title & $\mathbf{1 9 7 3}$ & $\mathbf{1 9 8 3}$ & $\mathbf{1 9 8 8}$ & $\mathbf{1 9 9 3}$ & $\mathbf{1 9 9 8}$ & Total \\
\hline A & 2 & 8 & 16 & 6 & 13 & 45 \\
A1 & 0 & 0 & 2 & 0 & 0 & 2 \\
A2 & 0 & 2 & 6 & 0 & 0 & 8 \\
A3 & 5 & 3 & 10 & 5 & 6 & 29 \\
\hline Subtotal in A & & & & & \multicolumn{3}{c}{84} \\
& & & & & $(38 \%$ of total $)$ \\
D & 2 & 1 & 11 & 7 & 9 & 30 \\
E1 & 0 & 0 & 0 & 0 & 0 & 0 \\
E2 & 0 & 0 & 1 & 0 & 0 & 1 \\
F & 0 & 6 & 8 & 3 & 6 & 23 \\
H & 1 & 0 & 1 & 1 & 3 & 6 \\
I & 0 & 3 & 6 & 2 & 2 & 13 \\
J & 0 & 1 & 3 & 0 & 2 & 6 \\
\hline
\end{tabular}

Subtotal in D-J

(36\% of total)

$\begin{array}{lllllll}\mathrm{A} 2 / \mathrm{D} & 0 & 2 & 3 & 2 & 0 & 7\end{array}$

$\begin{array}{lllllll}\mathrm{A} 3 / \mathrm{D} & 0 & 1 & 1 & 1 & 1 & 4\end{array}$

$\begin{array}{lllllll}\mathrm{D} / \mathrm{H} & 0 & 2 & 11 & 4 & 5 & 22\end{array}$

$\begin{array}{lllllll}\mathrm{A} 3 / \mathrm{F} & 0 & 0 & 1 & 0 & 0 & 1\end{array}$

$\begin{array}{lllllll}\mathrm{D} / \mathrm{F} & 0 & 0 & 2 & 0 & 1 & 3\end{array}$

\begin{tabular}{|c|}
\hline $\mathrm{E} 1 / \mathrm{D} / \mathrm{H}$ \\
\hline
\end{tabular}

$\begin{array}{lllllll}\mathrm{A} 2 / \mathrm{D} / \mathrm{H} & 0 & 0 & 1 & 0 & 1 & 2\end{array}$

$\begin{array}{lllllll}\mathrm{H} / \mathrm{J} / \mathrm{D} & 0 & 0 & 1 & 0 & 4 & 5\end{array}$

$\begin{array}{lllllll}\mathrm{A} 2 / \mathrm{H} & 0 & 0 & 0 & 2 & 0 & 2\end{array}$

$\begin{array}{lllllll}\mathrm{E} 1 / \mathrm{D} & 0 & 0 & 0 & 1 & 2 & 3\end{array}$

$\begin{array}{lllllll}\mathrm{H} / \mathrm{J} & 0 & 0 & 1 & 0 & 0 & 1\end{array}$

$\begin{array}{lllllll}\mathrm{A} 3 / \mathrm{J} & 0 & 0 & 0 & 0 & 1 & 1\end{array}$

$\begin{array}{lllllll}\mathrm{D} / \mathrm{F} / \mathrm{H} & 0 & 0 & 0 & 0 & 1 & 1\end{array}$

$\begin{array}{lllllll}\mathrm{D} / \mathrm{H} / \mathrm{A} 3 & 0 & 0 & 0 & 0 & 1 & 1\end{array}$

\begin{tabular}{|c|c|}
\hline $\mathrm{D} / \mathrm{E} 1 / \mathrm{A} 3$ & 0 \\
\hline
\end{tabular}

$\begin{array}{lllllll}\mathrm{I} / \mathrm{J} & 0 & 0 & 0 & 0 & 1 & 1\end{array}$

Subtotal in combination

57

( $26 \%$ of total)

$\begin{array}{lllllll}\text { Total } & 10 & 29 & 87 & 34 & 60 & 220\end{array}$
6. CD-ROM products;

7. computer languages or programming;

8. computer hardware;

9. possession of a degree in computer science;

10. networks, such as LAN or WAN;

11. Internet searching; 
TABLE 2

Job Ads by Institutional Class and Date

\begin{tabular}{lccccrrc}
\hline \hline Class & $\mathbf{1 9 7 3}$ & $\mathbf{1 9 8 3}$ & $\mathbf{1 9 8 8}$ & $\mathbf{1 9 9 3}$ & $\mathbf{1 9 9 8}$ & Total & \% \\
\hline Research Universities & 4 & 16 & 42 & 19 & 23 & 104 & $48 \%$ \\
Doctoral Universities & - & 3 & 17 & 2 & 6 & 28 & $13 \%$ \\
$\begin{array}{l}\text { Master's } \\
\text { Baccalaureate }\end{array}$ & 4 & 3 & 18 & 9 & 16 & 50 & $22 \%$ \\
$\quad$ Liberal Arts) & 2 & 5 & 9 & 3 & 11 & 30 & $14 \%$ \\
Associate Arts & - & 1 & 1 & 2 & 4 & 8 & $4 \%$ \\
\hline TOTAL & 10 & 28 & 87 & 35 & 60 & 220 & $100 \%$ \\
\hline
\end{tabular}

12. resources in electronic formats;

13. image technology or multimedia.

To assess job requirements relating to behavioral descriptions, the authors developed a set of codes from an examination of the pilot data and a review of the literature on organizational change in libraries. The paper by Roy Tennant was particularly helpful. ${ }^{24}$ The behavioral codes used were:

1. communication skills (includes oral and/or written);

2. interpersonal skills;

3. service orientation/public service;

4. work effectively with faculty, students, staff;

5. collegial environment;

6. creative/creativity;

7. energetic/enthusiastic/outgoing;

8. flexibility;

9. team member/team environment;

10. work in a changing, dynamic, expanding environment.

The authors analyzed a sample set of ads to determine the level of agreement in coding. One author did the job title coding, and both reviewed the coding and, in the event of disagreement, arrived at a consensus.

For the purposes of this paper, the authors have reported the analysis of three groups of jobs: administrative, reference, and a group that combined tasks usually described in the context of a single job. The first group, category A, administration (deans, directors, AULs, etc.), was analyzed because of the authors' interest in change in organizational structures in academic libraries. They expected to see some change in the duties and responsibilities of the top administrative positions over the period of this study, in particular, job ads that stated a description of organizational change from a hierarchical structure to a team-based, flattened structure.

The second group of jobs analyzed was category D, the general and subject reference jobs. The authors were interested in how electronic resources were being incorporated into the job. They also were seeking an indication of the growing role of instruction in the reference jobs, in particular, indications that reference jobs were becoming more active in their design instead of the more traditional and somewhat passive jobs that previous observers had described.

The third group of jobs comprised those that displayed a combination of jobs $(\mathrm{A} 2 / \mathrm{D}$, etc.), as shown in table 1 . Because the ultimate purpose of the study was to examine the changing nature of work in academic libraries, this latter group was of particular interest. These fifty-seven positions combine many of the tasks that have defined the work of the academic librarian: collection development, reference, and cataloging. Buttlar and Garcha had reported that a growing number of catalogers were engaged in reference desk work, collection development, and bibliographic instruction; these participants reported "job-sharing" on the rise. Robinson also had reported a widespread sharing of collection development work 
with other jobs. Dan Hazen has written about the changing work of collection development librarians and how bibliographers in large research libraries have always had combination jobs. ${ }^{25}$ The authors of this study interpreted these reports as reflecting a change in professional work in academic libraries and wanted to assess the changes.

\section{Results}

\section{Degree Requirements and Faculty Status}

A continuing topic of interest to academic librarians is whether the professional degree accredited by the ALA is still important to the field. In this study, over 80 percent of all jobs advertised between 1973 and 1998 required a degree from an ALAaccredited program. Indeed, all of the 1973 jobs required it. After that, there was a decline: 64 percent in 1983, 77 percent in 1988, 89 percent in 1993, and 87 per-

\section{In terms of behavioral requirements, strong communication skills, both oral and written, were mentioned most frequently.}

cent in 1998. Robinson reported that 79 percent of the 1980-1991 ads he studied required a degree from an ALA-accredited program. The largest libraries, those in Research I and II universities, are the ones most likely not to mention the ALA degree, but, in general, the policy adopted by ACRL in the 1970s continues to be embraced by the field:

The master's degree from a program accredited by the American Library Association is the appropriate professional degree for librarians. ${ }^{26}$

Of the 220 jobs analyzed, fifteen (6\%) required a second master's degree. Sixtyfive job ads indicated a preference or desire for a second master's. The expectation of some librarians who helped develop ACRL's policies in the 1970s, that more formal degree requirements would emerge in terms of required subject master's degrees, has not materialized.
The ALA-accredited degree has had widespread acceptance as the terminal degree for academic librarians; the second subject master's has not.

A second policy adopted by ACRL in the 1970s, Faculty Status of College and University Librarians, has been less widely accepted. ACRL has, as policy,

The intellectual contributions made by academic librarians to the teaching, research, and service mission of their colleges and universities merit the granting of faculty status. Faculty status for librarians should entail the same rights and responsibilities granted to and required of other members of the faculty. ${ }^{27}$

Forty-three percent of the ads in this study included faculty status. The fluctuation over the twenty-five-year period does not indicate any tendency toward significant change toward or away from faculty status: 40 percent of the ads in 1973, 31 percent in 1983, 46 percent in 1988, 54 percent in 1993, and 38 percent in 1998. Those libraries in which librarians are members of the faculty have well-established policies and practices. Although college and university administrators find faculty status for librarians in terms of hiring, promoting, compensating, and granting tenure to librarians onerous (as do some library directors), faculty status remains an important element in hiring in many libraries (less than $50 \%$ in this study, but a sizeable number of institutions nevertheless).

\section{Administrative Jobs}

Fifty percent of the eighty-four administrative positions in this study required some knowledge of, or experience with, automated library systems, most often described as a general knowledge of library automation (none in 1973; 50\% of ads in $1983 ; 50 \%$ in $1988 ; 40 \%$ in $1993 ; 62 \%$ in 1998). More specific aspects of automation, such as knowledge of particular bibliographic utilities or skills in online database searching, were not included in the administrative job ads. 
In terms of behavioral requirements, strong communication skills, both oral and written, were mentioned most frequently. Requirements for communication skills show a steady increase over the period covered: none in 1973; 25 percent in $1983 ; 50$ percent in 1988; 80 percent in 1993; and 45 percent in 1998. Communication skills were followed by interpersonal skills and the ability to work effectively with faculty, students, and staff.

Organizational change could not be observed. In the data on administrative jobs, little interest was identified in either "ability to work in a team environment" or change in the administrative patterns in libraries. Only one job ad, for an AUL position in a Research I library, stated explicitly that "The library system, as it evolves into a traditional line management approach, is seeking someone to initiate change." However, vision began to emerge in administrative ads. This is an indicator of change. The institutions seeking new administrators began to look for people able to identify new directions the library should take, labeling this as vision.

Throughout the period covered in this study, the job content for administrative jobs reflected the historical approach to library management. The interest in strong communication and interpersonal skills and a general knowledge of library automation had been added to, but not replaced, the requirements of management knowledge and the skills of planning, organizing, and budgeting. Generally speaking, the knowledge, skills, and abilities required for director and associate/assistant director jobs are well known and the job continues to be easily defined.

Leadership as a variable also emerged as a growing consideration in the administrative job category. Forty-two percent of all jobs required some evidence of leadership (none in 1973; $25 \%$ in $1983 ; 38 \%$ in $1988 ; 67 \%$ in $1993 ; 46 \%$ in 1998). The authors interpreted this, as they did the demand for vision, to mean that libraries confronting changing environments were seeking administrators who could define the new environments, place their librar- ies in them, and lead their staff members, as well as their users, to new services that reflected the new environments.

\section{Reference Jobs}

The duties of the reference librarian underwent some change in the twenty-fiveyear period of this study. No ads in 1973 mentioned instruction. The one job ad in 1983 mentioned "orientation," which the authors interpreted as the earlier form of the library's instruction program. Eight of the 10 ads in 1988 included instruction, seven included online searching, and six had collection development responsibilities. Two of the ads titled the jobs differently, one being information services librarian and the other being automated information access/reference librarian.

In the 1990s, instruction was included in all job ads. The addition of instruction to the reference jobs was a major change in the job of the reference librarian. Its inclusion in the program of academic libraries was codified in the 2000 Standards for College Libraries:

The library should provide information and instruction to users through a variety of reference and bibliographic services, such as courserelated and course-integrated instruction, hands-on active learning, orientation, formal courses. ${ }^{28}$

The standards built on the Guidelines for Instruction Programs in Academic Libraries adopted earlier by the ACRL.

Behavioral characteristics began to appear in the reference ads in the 1980s, particularly oral and written communication skills. These skills were common in the 1990s reference ads. Such skills are important to the implementation of an effective program of instruction.

In the 1990s, four ads included collection development, showing the move toward combining jobs.

In 1998, the variable, leadership, appeared in three of the nine ads. So, as in administrative jobs, libraries began to seek reference professionals able to re- 
spond to the changing environment brought about by the emergence of the Internet, to manage instruction, and to provide information found in all formats.

The title of reference librarian continued to be the most common title until 1998. In 1998, the reference jobs were called:

- electronic services reference librarian;

- information literacy librarian;

- library faculty/reference librarian;

- reference/agricultural librarian;

- reference/business librarian;

- reference/science librarian;

- reference/social science librarian;

- social science reference librarian.

One ad continued to use reference librarian. These jobs combined subject expertise, knowledge of electronic resources, and recognition of information literacy. They reflected an active, outreach type of position. All the reference jobs required a degree from an ALA-accredited program.

\section{Combination Jobs}

The emergence of the combination positions could be the result of budget concerns: "We must do more with less." However, the authors believe that the jobs in academic librarianship were shifting from the traditional, functional specialist positions to more expansive and complex jobs. It is clear that these types of positions were on the rise. In the data set from 1983, combination jobs represented 14 percent of the total positions advertised. The percentage increased to 25 percent in 1988, 31 percent in 1993, and 32 percent in 1998.

Although it might have been expected that computer-related skills would increase dramatically in the 1990s, the combination jobs were not laden with such requirements. In positions requiring reference services, online database searching was often mentioned and the cataloging positions referred to knowledge of the bibliographic utilities. However, there was no tendency to list numerous computer skills across the board. The most consistent computer-related skills were broad and general, for example, "working with resources in electronic formats" or "knowledge of computerized systems." These jobs demanded and expected professionals to have computer skills as part of their general background and preparation.

The requirement of behavioral traits also increased with time. The earliest data emphasized skills, not behaviors, in the ads; communication skills were listed in two jobs and only one mention was made of public services. In the 1998 set, however, communication skills occurred in twelve of the nineteen positions. Terms such as creativity, enthusiasm, and flexibility began to show up in the 1988 data and increased into the 1990s sets. Only in the 1990s did the concepts of team environment or changing environment appear.

Tennant suggested that it might be more productive to look at personality traits instead of specific skills when hiring for the future. ${ }^{29}$ These new combined positions showed a growing interest in behavioral characteristics. Librarians work with users; the skills needed to do that go beyond the usual knowledge base of librarianship.

\section{Discussion}

\section{Education and Training}

Most academic library jobs require a degree from an ALA-accredited program. Over 80 percent of the jobs advertised required it. A master's degree from an ALAaccredited program has been adopted by the field as the appropriate professional degree for academic librarians. In this study, research libraries were less likely to require the MLS degree than other libraries were. This finding supports the current surveys reported by the ARL, an organization comprising 123 libraries serving major North American research institutions. An evaluation of jobs reported in the ARL annual salary surveys for 1985, 1986, 1990, 1994, and 1998 revealed that a growing percentage of the professionals in these libraries were without the library degree. The ARL surveys allowed each library to use its own defi- 
nition of "professional." Although ARL libraries reported they require an MLS degree, more hires are being made without it. ${ }^{30}$ Does this mean that the profession is changing and that the MLS degree may no longer be important to the work of libraries? Possibly, but this is not apparent in the data from job ads. New specialists were being hired, and they came without the library degree. At the present time, however, the knowledge, skills, and abilities formed from a library and information science (LIS) education continue to dominate the academic library workforce.

In the past year, there has been growing interest on the part of the profession in determining so-called core competencies and in reviewing the course content in accredited LIS programs. The ALA hosted an invitational Congress on Professional Education in May 1999 to examine the initial preparation of professional librarians and to identify the core values that shape the library professional. The current set of Standards for Accreditation of Master's Programs in Library E Information Studies describe the curriculum as follows:

The curriculum is concerned with recordable information and knowledge, and the services and technologies to facilitate their management and use. The curriculum of library and information studies encompasses information and knowledge creation, communication, identification, selection, acquisition, organization and description, storage and retrieval, preservation, analysis, interpretation, evaluation, synthesis, dissemination, and management. ${ }^{31}$

This is the knowledge content that employers expect a professional librarian to know. The behavioral aspects being identified in job ads are rarely a part of the curriculum.

Few of the jobs advertised required a second master's or other advanced degree, although 30 percent of them included it as a desirable characteristic.
The field has incorporated computing technologies into all jobs. The computer requirements in the 1990s ads were stated in broad terms, not in specific skill requirements, which was a change from earlier years. Because the ALA-accredited degree is an accepted job requirement, the assumption of employers seems to be that a graduate's knowledge base will include knowledge of computer technologies as they relate to library and information science. The Standards for Accreditation state: "The curriculum integrates the theory, application, and use of technology." Thus, computer skills, a solid knowledge of technological design and application, and knowledge of information resources in all formats must be integral components of educational programs in LIS.

Because computing requirements are pervasive for successful academic library

\section{However, the administrative job ads did not reflect change in organiza- tional structures.}

performance and because computing technology, Web access, and information resources on the Internet constantly change, continuing education programs for staff are essential. Libraries cannot rely on new hires to bring the necessary up-to-date knowledge into the library; rather, a regular and systematic program for continuing education is necessary. Academic libraries have responded to the need for such programs, but a regular budget of some magnitude is now a budgetary necessity.

Instruction has become an integral part of every reference job, and some responsibility for collection development has emerged as an important component of these jobs. Job titles are displaying these content changes. How educational programs deal with these changes in jobs and the requirements for the knowledge base is an important question. Chris Avery and Kevin Ketches reported that library instruction is not taught formally in many LIS programs. ${ }^{32}$ However, programs should look carefully at what kinds of 
teaching skills and learning theories should be included in the curriculum to meet the instructional responsibilities now found in jobs. Similarly, although some programs include a course on collection management, such courses usually are elective, are taught by adjuncts, and are not taught regularly.

\section{Organizational Change}

Organizational changes have begun to appear in the more entry-level jobs where departmental and unit team environments are mentioned. This was expected because the reference and the combination jobs were beginning to show change in content and changing jobs generally are expected to be organized into different structures. However, the administrative job ads did not reflect change in organizational structures. Despite these suggestive changes, the data simply did not describe what the authors were searching for in terms of organizational structure. The results are tantalizing but require further investigation using different methods.

\section{Changing Nature of Work in Libraries}

The titles of reference jobs in the 1990s and the emergence of more combination jobs do point to the changing nature of library work, but the results are in no way definitive. They could reflect local requirements, but the authors' assumption regarding the data is that these job ads were at the "cutting edge" of change in the field.

In a recent assessment of sixty-one staff in research libraries, Stanley Wilder reported a decline of 63 percent in cataloger positions between 1990 and 1998 and an increase of 72 percent in functional specialist positions, defined as "media specialists or ... experts in management fields such as personnel, fiscal matters, systems, preservation, etc. ${ }^{\prime 33}$ There also was a decline in reference hires (22\%) and subject specialist hires (25\%) during this period. These data show how the research libraries were shifting resources from traditional jobs to new ones.

The growing requirement for behavioral skills, especially oral and written communication skills, in entry-level and well as administrative level positions, also suggests changes in the nature of the work librarians were doing. Technical skills continued to be important, but jobs now specifically required the ability to communicate well with people inside and outside the library. Requirements for "flexibility," "creativity," and "leadership" also suggest that jobs were changing and that libraries were paying closer attention to interactions between librarians and library users. The library as a passive warehouse of collections was no more. The library as an active agency providing information services to users and developing services based on information collections of all formats inside and outside the library was the new model.

Commentators, finding behavioral skills to be the overriding skills essential for success in library work, have not commented on who should teach these skills. With the widespread acceptance of the master's degree from an ALA-accredited program as a job requirement, the responsibility of these programs (fifty-six programs in the U.S. and Canada currently are accredited) is to be sure that the programs' content includes the fundamental knowledge and content of the profession. Yet most LIS programs do not include formal study of behavioral skills. There has been a growing emphasis on team projects and oral presentations, but instruction is not included in how to do a team project successfully or how to present an excellent oral or written report. Practice in doing such activities might be included in courses, but instruction in how to do it is not.

Commentators on the new technological requirements for people working with digital libraries are harsh in their comments on the education and training of librarians. ${ }^{34}$ They also ignore the necessary behavioral skills. That the job ads no longer include specific computer skills but, instead, state the requirements in general terms suggests that educational programs are doing well in providing students the grounding in technical matters now routine in academic library operations. 
The specific emphasis on good communication skills emphasizes the growing importance libraries are placing on information services, instructional tasks, and interactions with patrons. The requirements for these skills do not negate the need for a professional knowledge and base in content; the required master's degree in LIS is the shorthand requirement for these. What these requirements for communication skills emphasize is the need for library professionals to be able to interact with library patrons in many different ways.

Library managers know well how jobs change when an incumbent is in place. The incumbent can determine the nature of the job in many ways, and the job itself changes because of that. The authors suspect that many of the creative jobs in instruction have been developed by people already working in academic libraries. These librarians, challenged by the digital environment and determined to teach their students and faculty members about the new formats of informa- tion and new ways of accessing information, have created jobs with titles such as coordinator of instruction, information literacy librarian, and bibliographic instruction specialist. After these job have become common to academic libraries, which the authors believe is happening rapidly, ads for these jobs will appear regularly.

Organizational structures, like ideal jobs, can be designed rationally. Structures, too, are influenced by many factors: size, nature of the work, and internal and external environments are some of the classical variables used to study organizational structures.

To continue the assessment of the changing nature of library work, a more detailed and careful study of the jobs themselves, not just of the advertisements for these jobs, is needed. The survey approach used by Buttlar and Garcha and by Lynch got at actual job content. The actual job content then can help explain structural changes that also are ongoing in academic libraries.

\section{Notes}

1. Beverly P. Lynch, "A Framework for a Comparative Analysis of Library Work," College and Research Libraries 34 (Nov. 1974): 432-43.

2. David Block, "Emerging Personnel Requirements in Academic Libraries as Reflected in Recent Position Announcements" (1980). ERIC ED 215703.

3. David W. Reser and Anita P. Schuneman, "The Academic Library Job Market: A Content Analysis Comparing Public and Technical Services," College \& Research Libraries 53 (Jan. 1992): $49-59$.

4. Penny M. Beile and Megan M. Adams, “Other Duties as Assigned: Emerging Trends in the Academic Library Job Market," College \& Research Libraries 61 (July 2000): 336-47.

5. Hong Xu, "The Impact of Automation on Job Requirements and Qualifications for Catalogers and Reference Librarians in Academic Libraries," Library Resources \& Technical Services 40 (Jan. 1996): 9-59.

6. William C. Robinson, "Academic Library Collection Development and Management Positions: Announcements in College \& Research Libraries News from 1980 through 1991," Library Resources Technical Services 37 (Apr. 1993): 134-46.

7. Zhou Yuan, "Analysis of Trends in Demand for Computer-related Skills for Academic Librarians from 1974 to 1994," College Research Libraries 57 (May 1996): 259-72.

8. Margaret Foote, "The Systems Librarian in U.S. Academic Libraries: A Survey of Announcements from College $\mathcal{E}$ Research Libraries News, 1990-1994" College $\mathcal{E}$ Research Libraries News, 58 (Nov. 1997): 517-26.

9. Gary W. White, "Head of Reference Positions in Academic Libraries: A Survey of Job Announcements from 1990 through 1999," Reference \& User Services Quarterly 39 (spring 2000): $265-72$.

10. Richard J. Cox, "Archival Position Advertisements: Trends and Practices in the Information Age 1976-1990," in The First Generation of Electronic Records Archives in the United States: A Study in Professionalism, ed. Richard J. Cox (Binghamton, N.Y.: Haworth 1994), 97-130.

11. Ann W. Copeland, "The Demand for Serials Catalogers: An Analysis of Job Advertisements, 1980-1995," Serials Librarian 32 (1997): 27-37. 
12. Gary W. White, "Academic Subject Specialist Positions in the United States: A Content Analysis of Announcements from 1990 through 1998," Journal of Academic Librarianship 25 (Nov. 1999): 372-82.

13. Michele Valerie Cloonan and Patricia C. Norcott, "Evolution of Preservation Librarianship as Reflected in Job Descriptions from 1975 through 1987," College E Research Libraries 50 (Nov. 1989): 646-56.

14. Carolyn J. Mueller and Margaret V. Mering, "Serials Positions in U.S. Academic Libraries, 1980-1988: A Survey of Position Announcements," Library Resources E Technical Services 35 (Oct. 1991): 416-21.

15. Lois Buttlar and Rajinder Garcha, "Catalogers in Academic Libraries: Their Evolving and Expanding Roles," College E Research Libraries 59 (July 1998): 311-21.

16. Joan Giesecke, Sarah Michalak, and Brinley Franklin, "Changing Management Roles for Associate Directors in Libraries," Library Administration \& Management 11 (summer 1997): 17280 .

17. Janice Simmons-Welburn, Changing Roles of Library Professionals (Washington, D.C.: ARL, May 2000). SPEC Kit 256).

18. Lynch, "A Framework for a Comparative Analysis of Library Work."

19. Rutherford D. Rogers and David C. Weber, University Library Administration (New York: H.W. Wilson Co., 1971).

20. Arthur M. McAnally and Robert B. Downs, The Changing Role of Directors of University Libraries," College E Research Libraries 34 (Mar. 1973): 103-25.

21. Ibid., 107.

22. http://www.carnegiefoundation.org/classification/CIHE2000/2000_Classification.pdf

23. Zhou, "Analysis of Trends in Demand for Computer-related Skills for Academic Librarians from 1974 to 1994, , 260.

24. Roy Tennant, "The Most Important Management Decision: Hiring Staff for the New Millennium," Library Journal 123 (Feb. 15, 1998): 102.

25. Dan Hazen, "Twilight of the Gods? Bibliographers in the Electronic Age," Library Trends 48 (spring 2000): 821-41; _ Selecting for Storage: Local Problems, Local Responses, and an Emerging Common Challenge, Library Resources $\mathcal{E}$ Technical Service 44 (Oct. 2000): 176-83.

26. Policy 54.2. ALA Handbook of Organization 1998-99, 45.

27. Policy 54.5. ALA Handbook of Organization 1998-99, 45.

28. http://www.ala.org/acrl/guides/college.html

29. Tennant, "The Most Important Management Decision."

30. Martha Kyrillidow, "Educational Credentials, Professionalism, and Librarians," ARL: A Bimonthly Report on Research Library Issues and Actions from ARL, CNI, and SPARC 208/209 (Feb./ Apr. 2000): 12-13. 1992).

31. Standards for Accreditation of Master's Programs in Library Information Studies (Chicago: ALA,

32. Chris Avery and Kevin Ketches, "Do Instruction Skills Impress Employers?" College $\mathcal{E}$ Research Libraries 57 (May 1996): 249-58.

33. Stanley Wilder, "The Changing Profile of Research Library Professional Staff," ARL: A Bimonthly Report on Research Library Issues and Actions from ARL, CNI, and SPARC 208/209 (Feb./ Apr. 2000): 1-5.

34. William Y. Arms, Digital Libraries (Cambridge, Mass.: MIT Pr., 2000), 84-88. 